\section{Brand crisis management: the use of information for prevention, identification and management}

\author{
Alexandre Borba Salvador \\ Universidade de São Paulo, FEA, Business Management, São Paulo, Brazil \\ Ana Akemi Ikeda \\ Universidade de São Paulo, FEA, Business Management, São Paulo, Brazil
}

Received on

$11 / 08 / 2016$

Approved on 06/09/2017

Responsible editor:

Prof. Dr. João Maurício Gama

Boaventura

\section{Evaluation process:}

Double Blind Review

\begin{abstract}
Purpose - To understand, from the management perspective, the use of information on brand crisis management in moments involving prevention, identification and management.

Design/methodology/approach - This article is the result of an exploratory, qualitative study. Primary data was collected through interviews with marketing executives and crisis management specialists.

Findings - We concluded that managers use information in very different ways, and, taking possession of information and decisionmaking attitudes into account, four groups of crisis managers were found.

Originality/value - In order to contribute to the expansion of academic knowledge in the field of marketing administration and brand crisis management, this study presented the crossing of three different fields (information systems, brand crisis management and organizational development) to structure knowledge concerning brand crisis management. From the managerial perspective, certain crises could be avoided by monitoring internal and external information, and by identifying problems in their early stages. From the social perspective, reducing brand crisis cases positively affects society as a whole (organizations and individuals).
\end{abstract}

Keywords - Brand crisis; information; crisis management.

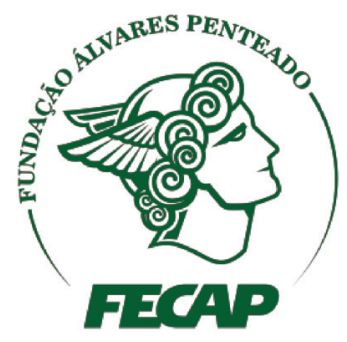

Review of Business Management

DOI:10.7819/rbgn.v20i1.3583 


\section{Introduction}

Technological advances inherent to Web 2.0 and the two-way communication provided by the internet and social networks have boosted greater content exchange not only between consumers and brands but also among consumers (Kliatchko, 2008). Consumers now have greater influence on brand management. Their social behavior on the internet allows for increased engagement with brands, thanks to interaction and relationships. Ease in message sharing within the network itself and among different networks multiplies the visibility of objects that the audience which generates content is most sensitive to.

The rise of the user-generated content (Laroche, Habibi, Richard, \& Sankaranarayanan, 2012) has reduced brands' control of information. Greater disclosure of problems concerning brands would increase the extent of image crises. Protecting brands through crisis management has become increasingly interesting to organizations (Coombs \& Holladay, 2002; Dawar \& Pillutla, 2000; Siomkos, Triantafillidou, Vassilikopoulou, \& Tsiamis, 2010). Monitoring companies' internal and external information can help in this action (Rosa, 2001). Contemporary managers must be prepared to make decisions in reduced-control-ofinformation (Coombs \& Jean, 2014; Rosa, 2001; Silva Neto, 2010) and increased speed, variety and volume of information scenarios (Biesdorf, Court, \& Willmott, 2013; Manyika, Chui, Brown, \& Bughin, 2011).

If, on the one hand, brands have never been so sensitive, on the other, managers have never had so much information available to prevent and identify problems that could lead to crises. Major research on brand crises, based on experiments, surveys and quantitative analysis of internal reports, has focused on factors that influence different types of crises, and on their financial consequences for brands, as well as on their financial, psychological and physical consequences to society. The objective of this study is to understand, from the managerial perspective, the use of information on brand crisis management during prevention, identification and management moments. It is justified by the combined importance of brands to current businesses and increased information available to managers, of society's empowerment, of brand exposure and the lack of research investigating the use of information by managers in this context.

Recent studies on brand crisis management have focused on the use of social networks as a means of monitoring and spreading crises, as well as on their effects on brand images (Hood, 2012; K. Kim, J. Kim, \& Reid, 2017; Koerber \& Zabara, 2016; Ngai \& Falkheimer, 2017; Pace, Balboni, \& Gistri, 2015; Park, 2016; Roh, 2017; Roshan, Warren, \& Carr, 2016; Rubel, Naik, \& Srinivasan, 2011; Salvador, Strehlau, \& Ikeda, 2015; Salvador, Ikeda, \& Crescitelli, 2017)the \{IKEA\} cuddle toy Lufsig was connoted as a symbol of the Chief Executive (CE. This paper is a scientific contribution, since it addresses crises from decision- makers' perspective, opening up a new research front at the intersection of knowledge concerning brand crisis management, information management and organizational development.

\section{Theoretical references}

This project began with greater bibliographical research than the focus of this research. Based on that initial analysis, this theoretical framework was structured in four parts, first approaching the contemporary weakening of brands, moving on to crisis management in its early stages - with increasing available information - and ending with action to tackle the crisis.

\section{I Brand weakening}

A brand may be understood as a basis upon which a story referring to a product's special qualities may be told. It is the main repository of possible meanings in consumer culture, both as to location as well as to creation (Sherry, 
2006). A brand can also structure and organize information about the product, and help estimate the meaning and value of product attributes (Erdem, Swait, Broniarczyk, \& Kapferer, 1999), indicating a certain level of quality to be expected by consumers (Hakala, Svensson, \& Vincze, 2012), and increasing consumer confidence in its promises. Brand design and its value creation are the result of understanding all brand manifestations, whether planned by its legal owners, whether produced by consumers, employees or other stakeholders (Semprini, 2010). Following the evolution of the internet and of social media, consumers began to realize the power of their voices in society and, using new formats and means, started to produce contents against and in favor of brands (Kliatchko, 2008; Lovett, Peres, \& Shachar, 2013; Pace et al., 2015).

Brands have never been so important to their holders, and, at the same time, so sensitive to public opinion. The transformation of a previously passive audience into issuers of brand messages (Kliatchko, 2008) represented both increased brand fragility facing empowered consumers as well as the possibility of greater attention to brand information in a now easily monitored environment.

\subsection{Brand crisis management and the first moments of a crisis}

Crisis is a non-routine, unexpected and sudden event that creates uncertainties, threatens organizations' priority objectives, and that may cause financial losses and erode corporate reputations (Cleeren, Heerde, \& Dekimpe, 2013; Coombs, 2007b; Siomkos et al., 2010). Crises cannot be solved by routine procedures, and typically result in negative publicity, which may harm corporate images (Rosa, 2001) and stakeholders - physically, financially or emotionally (Coombs, 2007b; K. Kim et al., 2017). Brand crises can happen because of product defects, social responsibility problems, bad corporate behavior, executive misconduct, bad business results, spokespeople's bad behavior or controversial attitudes, loss of public support or disputes over ownership. In cases involving product defects, although the purpose of a recall campaign is to address a potential safety issue, it also reveals to society flaws in companies' control processes (Greyser, 2009; Kalaignanam, Kushwaha, \& Eilert, 2013).

Organizations' attitudes facing a crisis directly influence society's perceptions and to whom it attributes responsibility (Siomkos et al., 2010). Answers can could range from denial of responsibility to acceptance of responsibility, followed, as well as by legal obligations (super effort), by efforts to compensate society. A stance perceived as false, careless or irresponsible would strengthen the attribution of blame to the organization. A stance perceived as transparent, fair and careful would increase society's willingness to believe in the organization's version and forgive it (Rosa, 2001). At a time of crisis, there would be a race between the organization and the media for leadership in the communication process. The speed and credibility of information would be crucial (Coombs, 2007b; K. Kim et al., 2017; Koerber \& Zabara, 2016; Rosa, 2001; Silva Neto, 2010).

In cases involving human failure, clear standards of governance and accountability as well as codes of conduct would be required, as well as monitoring of their implementation. Integrated computer systems could at the same time train and monitor organization representatives, as one of the components of a big data use plan (Gobble, 2013; Manyika et al., 2011). The main indicators referring to the brand's controllable variables should be constantly monitored and analyzed for business management (Biesdorf et al., 2013). This information would also be important in defining the parameters of the crisis, such as those that refer to the competitive scenario, to price elasticity, to the distribution and quality of the product on display, and to the evaluation of current advertising campaigns (Cleeren et al., 2013; Kalaignanam et al., 2013; Rosa, 2001). Brand and corporate reputation monitoring in 
different audiences in digital media - by means of digital research tools - could signal the beginning of movements outside the standards of normality, thus enabling anticipation to the crisis (Silva, 2010).

Given the increasing trend in the number of crises, organizations should assume that a crisis can occur at any time (Dawar \& Pillutla, 2000; Siomkos et al., 2010). Thus, a company's routine would involve preparing management for a crisis. From products' point of view, this would mean keeping control of all variables that could influence its quality, including data control inputs and production sensor records, as well as taking care of products' traceability following distribution and consumer reactions through a Customer Service Channel and social networks. From the leadership's point of view, the convening of an already established crisis committee and the use of a crisis room could raise awareness concerning available information, make multifunctional analysis easier and favor the speed of decision-making (Rosa, 2001; Silva, 2010).

Increased brand crises (Cleeren et al., 2013; Dawar \& Pillutla, 2000; Siomkos et al., 2010); the empowerment of consumers as generators of brand messages (Gensler, Völckner, Liu-Thompkins, \& Wiertz, 2013; Kaplan \& Haenlein, 2010); and the increasing speed, volume and variety of information (Biesdorf et al., 2013; Brown, Chui, \& Manyika, 2011) all demand greater skills from managers in the use of information and in decision-making related to crisis management.

\subsection{The increase in available information}

A good information system is essential for obtaining relevant data for marketing decision- making - the more correct and relevant the information, the greater the likelihood of success (Berenson, 1969; Chiusoli, 2005; Cox \& Good, 1967). The concept of a marketing information system (MIS) was defined by Cox and Good (1967, p. 145) as a series of procedures and methods for the planned collection, analysis and presentation of information on a regular basis for use in the marketing decision-making. To Chiusoli (2005), a marketing information system could be structured by its data sources (internal or external data), input subsystems (internal database, marketing intelligence and marketing research), data processing (system to support marketing decisions), and the information for decision-making (planning, structure, segmentation, positioning, product, distribution, price and promotion) directed at the decisionmaker in marketing (Chiusoli, 2005).

With the increase in computational capacity, the 1990 s became known as the decade of networked society and transactional data analysis (Chow-White \& Green, 2013). This moment of change was also marked by differences in the knowledge and the speed with which new technologies were adopted. Competitive intelligence analysts were ranked by Rouach and Santi (2001) according to their expertise in information management and attitude offensiveness in five profiles: sleeper, reactive intelligence analyst, active intelligence analyst, aggressive and warrior intelligence analyst (Rouach \& Santi, 2001), highlighting the importance of attitude in the search for and analysis of available information (Figure 1). 


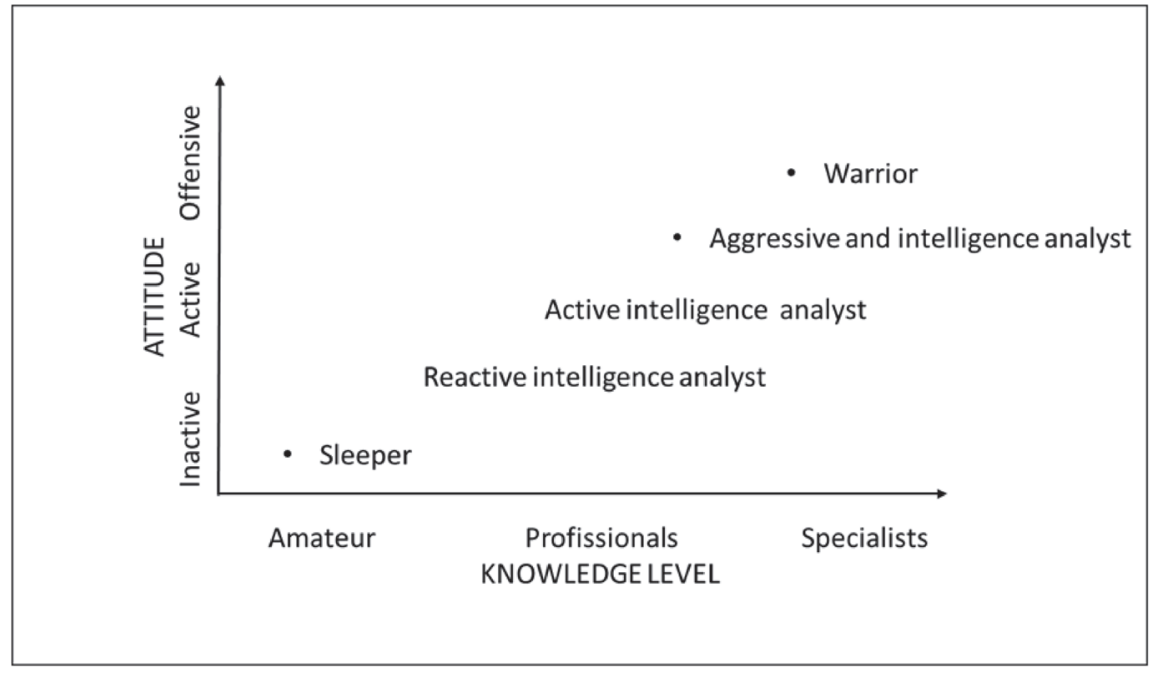

Figure 1. Profile of competitive intelligence analysts. Adapted from Rouach, D., \& Santi, P. (2001). Competitive Intelligence Adds Value: Five Intelligence Attitudes. European Management Journal, 19(5), p. 556. http://doi.org/10.1016/S0263-2373(01)00069-X

\subsection{Actions facing a crisis}

Decision-making moments and change generate discomfort in many executives. Exposure and fear of making mistakes, hidden private goals, risk aversion, lack of resource vision, and problems with incorrect accountability are important barriers to the adoption of change (Keagan \& Lahey, 2011; W. C. Kim \& Mauborgne, 2011; Kotter, 1997, 2012). Technological paradigm shifts as described by Rouach and Santi (2001) and moments of crisis force change and cause discomfort and anxiety (Bridges, 1986; Bridges \& Mitchell, 2000; Kotter, 1997). The current moment is of change in information technology, that is, the volume of critical data and processing capacity has increased exponentially, leading to a large volume of poorly structured information that could be analyzed for obtaining useful information (Dijcks, 2013). There is technology for monitoring information in different environments (internal and external) in different formats (spreadsheets, reports, photos, publications on social networks, news), generated by several stakeholders (employees, competitors, consumers, journalists, government agencies). This monitoring and information analysis in real time is essential to rapid identification of problems that might generate brand crises.

Proposition 1: There is a great difference in the level of information valorization for identification and prevention of brand image crises.

The imminence of a brand crisis should create the sense of urgency needed to bring managers to work preventively, in order to minimize its impact (W. C. Kim \& Mauborgne, 2011; Kotter, 1997; Schlesinger, 2008). The increase in tools for information monitoring and analysis would enable the identification of problems that could evolve into crises in their early stages. Rapid detection of problems and causes associated with the management of a senior autonomous team (a crisis committee) could also minimize negative effects. The prior establishment of a crisis committee, their training and their summoning would also influence managers' preparation for a crisis (Bridges, 1986; W. C. Kim \& Mauborgne, 2011; Kotter, 2012; Silva Neto, 2010). During a crisis, the pressure for making the right decision in a timely manner requires an 
organization's rapid mobilization. Listed below are some of the competences and abilities found in leaders who succeed in times of change according to Bridges, 1986; Keagan \& Lahey, 2011; W. C. Kim \& Mauborgne, 2011; Kotter, 1997; Sirkin, Keenan, \& Jackson, 2011:

a) Ability to see the whole picture and to define the problem situation,

b) Ability to define a perspective for the problem situation,

c) Ability to train the team that will make the change,

d) Commitment, integrity, resilience and communication skills.

Proposition 2: Even in possession of information, managers react differently on the verge of a crisis.

In this context of transformation in the form of communication and pressure generated by a crisis, it is reasonable to question, once again, whether different behaviors would affect the way marketing executives seek out information, and whether the former would affect decision-making based on that information in a moment of urgency generated by a crisis. Facing these doubts, three questions arise: What types of information are used in a brand crisis? How are they obtained? How do managers react to a crisis?

\section{Methodological study procedures}

The objective of this study is to understand the use of the information in brand crisis management, from the perspective of managers, at moments of prevention, identification and management of a crisis. Empirical research can be classified as exploratory (Onwuegbuzie \& Leech, 2005; Selltiz, 1974), qualitative as to the paradigm (Flick, 2004), and direct, through the use of in-depth interviews, in technique and procedure (Flick, 2004; Marshall \& Rossman, 1995). Analysis was carried out through the combination of global analysis techniques and content qualitative analysis techniques (Flick, 2004; Mayring, 2014).

Overall content analysis was performed to obtain an overview of the thematic spectrum of the text to be analyzed (Flick, 2004). At the end of this stage, keywords were established and segments to be analyzed by the qualitative content analysis were selected. One of the main aspects of the content qualitative analysis is the creation and application of categories obtained a priori. Categories are brought to the empirical material, and then contrasted and complemented to reduce the said material (Flick, 2004). According to Mayring (2014), the objectives of content qualitative analysis are to keep the benefits of systematization and to adapt it to a qualitativeinterpretative application.

So as to ensure that the same procedures, when carried out by other researchers, would lead to similar results, thus ensuring the reliability of qualitative empirical research according to Flick, 2004; Mayring, 2014; Yin, 1998, the following occurred:

a) Creation of a priori categories based on the theoretical framework,

b) Use of a semi-structured script,

c) Systematic analysis,

d) Definition of a research protocol based on case study models (Yin, 1998).

For content qualitative analysis, four categories were defined a priori, based on the sequence of events identified in the theoretical framework: prevention, monitoring, existence of a crisis committee and problem detection. Each category was split into subcategories that served as a basis for the interview script.

At the end of the analysis, in the conclusion, lessons learned will be summarized and presented using a conceptual map developed using open source software Cmap, from the Florida Institute for Human \& Machine Cognition (IHMC). Conceptual maps are graphic organizers made up of concepts and propositions that represent knowledge and facilitate the learning process (Aguiar \& Correia, 2013). 
We interviewed six marketing managers who had a lot of experience in brand image crisis management (marketing managers and communication managers), a social networking monitoring specialist (CEO of a social media monitoring company), and a public relations specialist (director of a press office). Managers with recent experience in crisis management were identified from the brands crisis research in newspapers and in the PROCON-SP site, and the first contact was made through e-mail. From this first contact on, recruitment continued using the snowball technique (Godoi \& Mattos, 2006): certain managers indicated others as being more suitable for the research. Professionals from national and multinational companies of different sizes and sectors were interviewed, and, as a condition for participating in this research, executives requested confidentiality concerning their names, as well as the companies they represent. When cited, companies will be identified with letters A (multinational food sector), B (multinational food sector), C (multinational, hygiene and beauty sector), D (multinational, education sector), E (national, food sector) and F (multinational, technology sector). The interview script was pretested and later adjusted to ensure a better flow in the interview. The pre-test interview was discarded. Interviews lasted about 40 minutes and were held at convenient locations for respondents - offices, cafes and restaurants. Data collection took place during the second half of 2014. Interviews were audio recorded and transcribed in full (Mayring, 2014).

\section{Presentation of analysis and conclusions}

Analyzes and results presentation follow the structure defined by the main subcategories defined (a priori) before the content qualitative analysis: prevention, monitoring, existence of crisis committee and problem detection. At the end, results of the joint analysis, that is, considering theoretical references, and analysis of the interviews will be presented (Flick, 2004; Mayring, 2014).

\section{I Crisis prevention}

A large difference was found in the state of awareness / readiness of managers' companies before the crises, which ranged from no question about the possibility of their occurrence to a great state of attention and dedication to prevent their occurrence or development. In the intermediate stage, we found a company that had procedures for establishing a crisis committee and crisis management, but that felt its processes were frail, because they had faced a small quality problem a few months before recall. This experience made it clear to the company that the processes were not as robust as theory had stated. This put the company in a state of attention, enabling a rapid reaction when the new crisis broke out.

It was observed in empirical research that certain multinational organizations already had training and crisis committee processes that had been established by the headquarters. Learning as to crises, obtained in other operations (usually in other countries), somehow interfered in the local settings. However, knowledge transfer did not prove sufficient to sensitize and prepare local executives since, in interviewees' statements, training is seen as a bureaucracy required by the parent company. According to the manager of company A, "theoretically, the company was prepared [for a crisis], and had certain crisis procedures; but far from being enough for a crisis of this size, however... people were not prepared for it".

According to one of the experts, president of a monitoring social networking company, a company like his lives the crisis management every day and the learning from other customers turns into knowledge to be transferred. In addition, according to him, the current technology already enables applications in monitoring and prevention, unknown to brand managers. Public relations agencies - managers of the corporate image of many companies - and their executives 
are also a source of experience. For another specialist, director of Service and Planning for a global public relations agency, some companies are already beginning to glimpse that, with the support of consulting and advisory, they can leverage their expertise and resources and start working on prevention more effectively. She said: "A good crisis is the one nobody heard about". For both of them, "a good crisis" is one that has been identified in its early stages and treated surgically so that it does not gain visibility.

\section{2 Crisis monitoring}

Variation found in the monitoring and prevention forms was very large as well. All the companies had a customer service channel (SAC), usually via letter, telephone, e-mail and social networks. The service in digital social networks occurred either passively, when the consumer write his complaint on the company's digital properties or on complaint sites (SAC), or actively, when the company monitors its brands in the open pages of different social networks and proposes to interact with consumers and respond when its brands are mentioned (SAC 2.0). The manager of the company E declared that the company offers, as a consumer contact channel, only the option of e-mail, directed to an employee whose function was not exclusively this one. In addition to SAC and SAC 2.0, other usual tools for preventing and identifying crisis were the internal quality controls and customer reports.

The manager of the company F presented a more active role in crisis prevention, as she monitored a proprietary discussion forum on the internet among consumers, technology experts (passionate about the topic, not hired by the company) and technicians of the company. She also monitored the several service systems of her partners (authorized technical assistance), classifying the complaints by type of problem, severity and time of the open occurrence.

Internal systems with different levels of automated integration and accuracy have been found, ranging from controls performed in spreadsheets (Excel) and electronic message systems (e-mail) to integrated ERP systems. Monitoring social networking is not yet a common and routine practice in companies. Figure 2 illustrates a continuum between the more robust and less robust marketing information systems (MIS) and the position of the respondents' organizations identified by letters A to F.

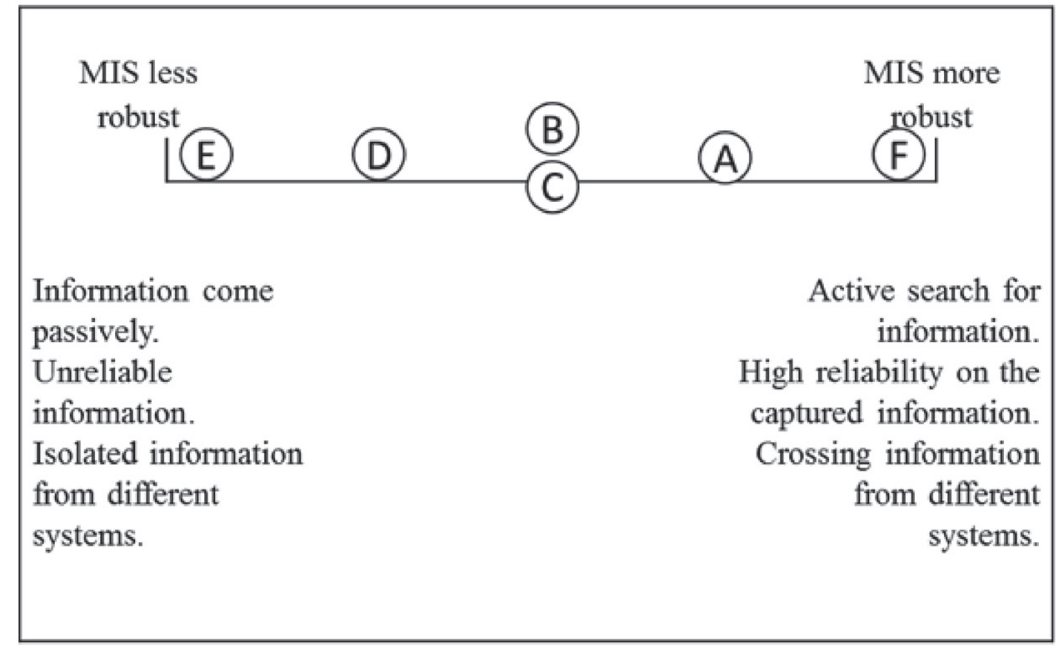

Figure 2. Robustness of information system. 


\subsection{Existence of a crisis committee}

Half the companies surveyed have already had a crisis committee identified and trained in the event of a crisis - multinationals that received training for guidance of their headquarters. Whether due to a previous recall, or because consumers exposed problems with products on social networks, these companies had already a history of crisis. Apparently, this relationship raises the assumption that companies start to worry about the crisis management at the time they are exposed to their impact, either local companies or international ones. Previous experience would generate the sense of urgency required for the creation of procedures for crisis prevention and management, but the distance in time and space would reduce awareness and give managers a sense of security. To the manager of company B, "[the company] is never structured enough...there is a crisis committee that is activated; usually people are already, you know, trained. Nevertheless, no one is ever prepared". In the perception of respondents, crisis management training does not prepare managers to adequately deal with crises. Although they are trained, managers do not feel prepared facing a crisis.

\subsection{Detection of a problem}

The crisis detection was a unique moment for each case; however, one can identify a greater or lesser control and reliability of the company's information and readiness for action. In the most critical case, the company had carried out few tests on its product before launching. Although they found problems in the samples tested, the managers considered the problem an isolated case and followed up with the launch plans: start of the commercialization by the distributors and carrying out of the launching event. According to the manager of company E's report, "launching of the product was at the [name of the theater], it was very cool... There were a lot of celebrities in the audience, there was media, newspapers, magazines, TVs... several models-promoters entered the theater, distributing the [packaging] to be opened by the audience. They didn't open it... Just a few [people] did". Even after having problems with product performance in the launching event for retail, media and opinionmakers, the company chose to continue with the commercialization and track consumers reviews on social networks. Following two months of sales, the increase in complaints led the company to decide to withdraw the product from the market, suspending sales and correcting the packaging problem.

Managers from two other companies (A and B) stated that they had a very similar onset of crisis. They received from the Sales field the first complaints about problem in the product. Consumers contacted retailers, which reported the sales field. The sales field reported the Quality Department. In one case, when he felt lack of mobilization in the Quality field, the regional sales manager contacted the Marketing manager. In both cases, companies did not have full confidence in their product traceability system. There were inconsistencies in the production reports, and the companies decided to call the recall spontaneously.

Preventively, the manager of company F worked with a robust information system where rarely something is beyond control. When this happens, processes are reviewed. In certain cases of crisis, she admitted her guilt; in others, however, her decision was to deny consumers' complaints through solid evidence that consumers were trying to defraud the company. The possibility of distinguishing between the two cases results from consistency of information about customers and the product in different systems. Information availability, the information cross-referencing from different sources and the reliability of the available information enable the anticipation and the decision-making. However, this is insufficient if, even in the possession of the information, the manager does not carry out the analysis and take the necessary decision to minimize the crisis. Some managers demonstrated and declared higher 
level of readiness before the first signs of a crisis. Apparently, this greater readiness resulted from an organizational culture focused on prevention, with greater mobilization in face of surprises, with the acceptance of the real possibility of a crisis and a clear definition of a management committee, with defined and structured management, communication and monitoring processes.

\subsection{Joint analysis of the theoretical framework and interviews}

Considering the availability of information and the realities found in interviews with crisis managers and specialists, we can position managers in different groups regarding the use of information at the time of prevention and identification of brand crises. In the first group are positioned managers who make decisions based on experience (feeling) and do not actively seek information for the decision process. At the time of crisis and identification prevention, they give little importance to brand and consumer monitoring and seldom relate information from different sources. At the other extreme are managers who actively seek information to identify the potential onset of a crisis and act in order to prevent it from occurring. They use their resources to monitor consumers, customers, the media, opinion makers and suppliers (service providers). The information from different systems is processed and analyzed together, even if this processing and analysis are not yet automated. The group works in a preventive way and manages, in a way, to act in the early stages of a potential crisis in an assertive way, minimizing the chance of its growth. In the middle of this continuum are managers who have already recognize the need for reliable and integrated information, but do not yet work with integrated information from different sources, or do not monitor their brands preventively, or do not access consumers more actively. This group can identify the crisis in its early stages, but not in time to prevent its onset. Figure 3 illustrates the arrangement of managers in this continuum.

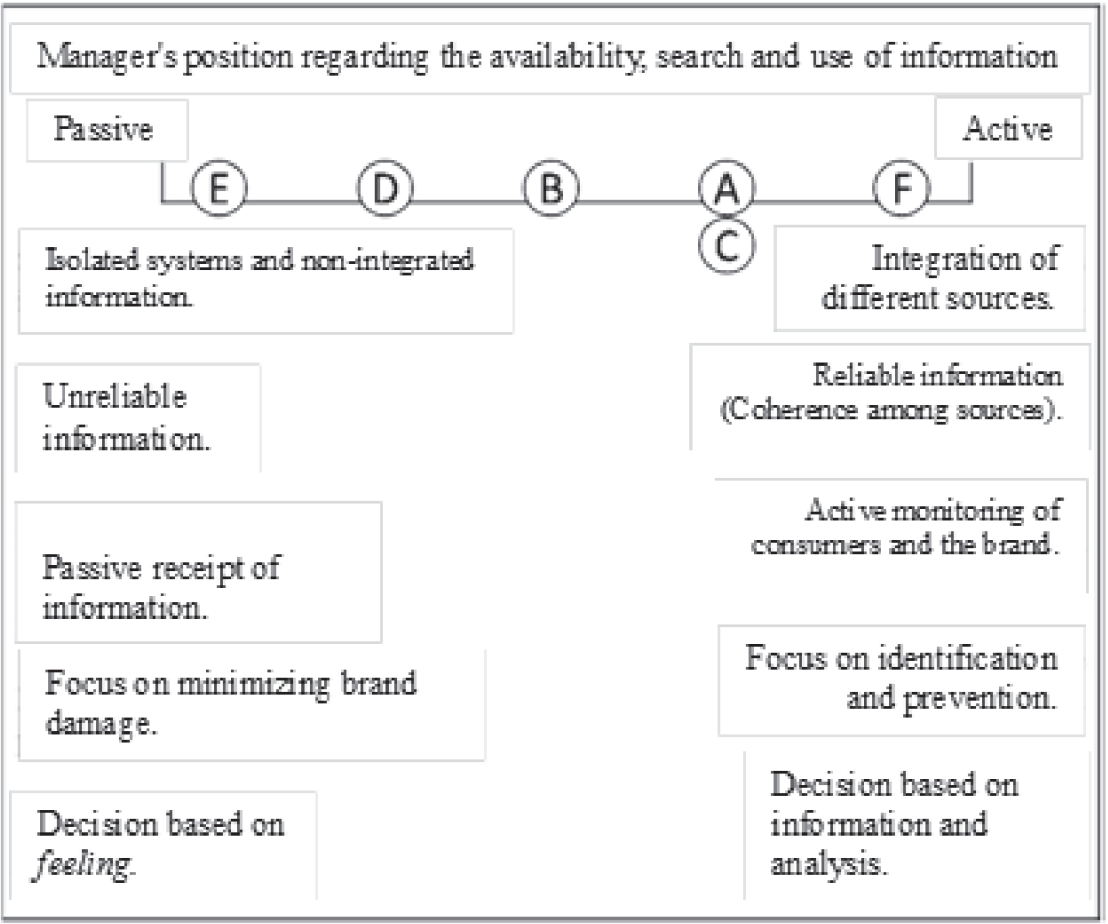

Figure 3. Continuum concerning the attitudes of managers. 
Organizations with vision on crisis have formal procedures and compliance rules that should oblige managers to invest in prevention, monitoring, and analyzing prevention-related indicators. However, the mere existence of compliance rules does not ensure that managers are prepared to act properly in a crisis. The existence of monitoring tools and procedures for the formation of the crisis committee is not enough per se; it is necessary a stage of attention and recognition of the brand's fragility in the contemporary context, as well as of the relevance of the harmful effects of a brand crisis (Cleeren et al., 2013; Coombs, 2007a; Siomkos et al., 2010). Currently there is technology available to improve the monitoring, identification and prevention of brand crises (Dijcks, 2013; Gobble, 2013; Manyika et al., 2011). Apparently the barrier is not technological anymore, but human. Even with the use of appropriate monitoring tools and corporate crisis management procedures, analysis and decision depend on the manager (or group of managers). The probably correct decision would result from the correct information, with the correct processing, and poorly prepared managers for the use of information would tend to decide rashly (with insufficient information or superficial analyzes) or belatedly (increasingly seeking more information); however well trained managers would know how to balance the necessary information with the timing of decisions.

The research results analysis suggests the acceptance of propositions 1 (there is a great difference in the valorization level of the information for identification and prevention of brand image crises) and 2 (even possessing the information, managers react differently on the imminence of a crisis). Some managers have a policy of active search for information, while others receive them passively. Managers react differently even with the ownership of relevant information. Information about the imminence of a problem that could cause a crisis does not give some managers the sense of urgency so much needed for the necessary mobilization at a time of crisis.

Based on the empirical research analysis and on the theoretical reference analysis, it was possible to identify two dimensions that influence the reaction to the crises, the first related to the information possession (having information) and the second related to its use (having attitude). At the intersections of these two dimensions, four profiles of brand crisis managers were identified: the boiled frog, the hyena, the eagle and the ostrich (Figure 4).

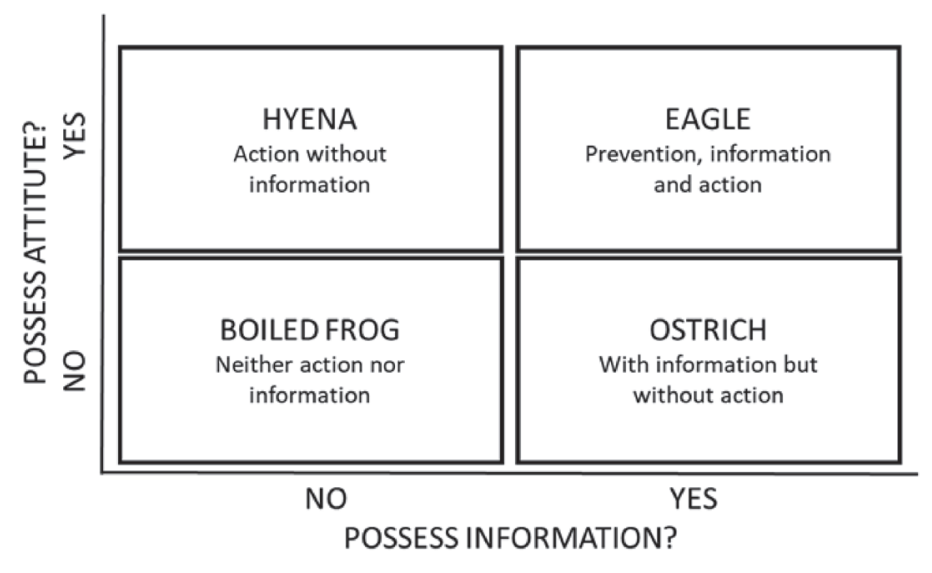

Figure 4. Profile of managers regarding the possession of information and regarding attitude. 
The "boiled frog" represents the manager who does not value information and has no attitude in the face of little evidence; it is a reference to the frog which, when placed in a pan of cold water, does not jump when the water boils and dies while being cooked, without realizing the change in temperature. According to Bridges (1986), the pressure for change could lead certain executives to a feeling akin to mourning, and may create the feeling of paralysis due to lack of identification, disengagement and disenchantment. The "ostrich" represents managers who, even in possession of information, prefer to ignore the imminence of crisis; it refers to the ostrich, which puts its head in the earth so as not to have visual contact with the threat. The "hyena", a reference to the noise the animal makes when alerting others, represents managers who try to warn the corporation of the risks of a crisis, but would have low credibility for his lack of information. This profile was not found in this research. However the reasonableness of its acceptance comes from the confrontation with the behaviors pointed out in the change management bibliography: managers pressured by previous failures, culture with errors intolerance and inadequate accountability could lead to behaviors that are exaggeratedly opposed to the lack of urgency sense (Keagan \& Lahey, 2011; W. C. Kim \& Mauborgne, 2011; Kotter, 1997). The "eagle", referring to the animal's excellent ability to map the territory in search of prey and threats, represents managers who actively seeks information, analyzes it, and takes preventive decisions to avoid crises or control their effects before they grow. He would have motivation, commitment, sense of urgency, resilience and integrity (Keagan \& Lahey, 2011; W. C. Kim \& Mauborgne, 2011; Sirkin et al., 2011).

Identifying the style of the person responsible for crisis management and for the implementation of corrective actions for the information systems improvement and use of information would enable advances in crisis management. Their results would include improvement in prevention, lower occurrence of generative problems, identification of problems and causes in the early stages, and faster and more structured decision making. Failure to consider the real possibility of a crisis and budget constraints lead to trade-offs investment, with prioritization of investments with financial results more easily calculated. The sensitization of the brands' fragility, the increased occurrence of brand crisis and its effects on business as well as the awareness of the possibility of minimizing problems with new monitoring possibilities of the internal and external environments are important facts that lead further and make progress towards increasing the sense of urgency and strengthening of a culture of prevention.

Identified the lack of information or lack of action, it is up to the organization's senior leadership to define the action plan, assessing the manager's ability to adapt or the need to substitute him (W. C. Kim \& Mauborgne, 2011; Kotter, 1997, 2012). The ultimate consequence of the identifying action of the managers profile is the reduction of both, the financial losses to the corporations owners of the brands and the financial and psychological losses to the society and, finally, of the possible physical damages to the consumers.

\section{Final considerations}

Based on the objective of understanding the information use in the brand crisis management in times of prevention, identification and management by the managerial perspective, this exploratory study identified a major difference in the information use by the managers. While some managers act towards prevention and actively seek information for the rapid detection of crisis-generating problems, others act passively, with little structured information systems, without considering the possibility of a crisis in their brands.

The empirical research also suggests that the possession of information about a possible problem is not enough to initiate the mobilization necessary for the crisis management and for the 
minimization of its negative effects. The research highlights the existence of different managers' profiles, to whom it is not enough to have information, since it is also necessary to have an attitude for the information use. The existence of previous experience, a culture that values prevention and well-structured information and crisis management processes are factors that influence the rapid identification of a crisis, generating a sense of urgency and a rapid response in face of the evidence. The existence of wellstructured processes increases the quality, speed, and reliability of information. Figure 5 provides a conceptual map on the brand crisis and its various influences (Aguiar \& Correia, 2013).

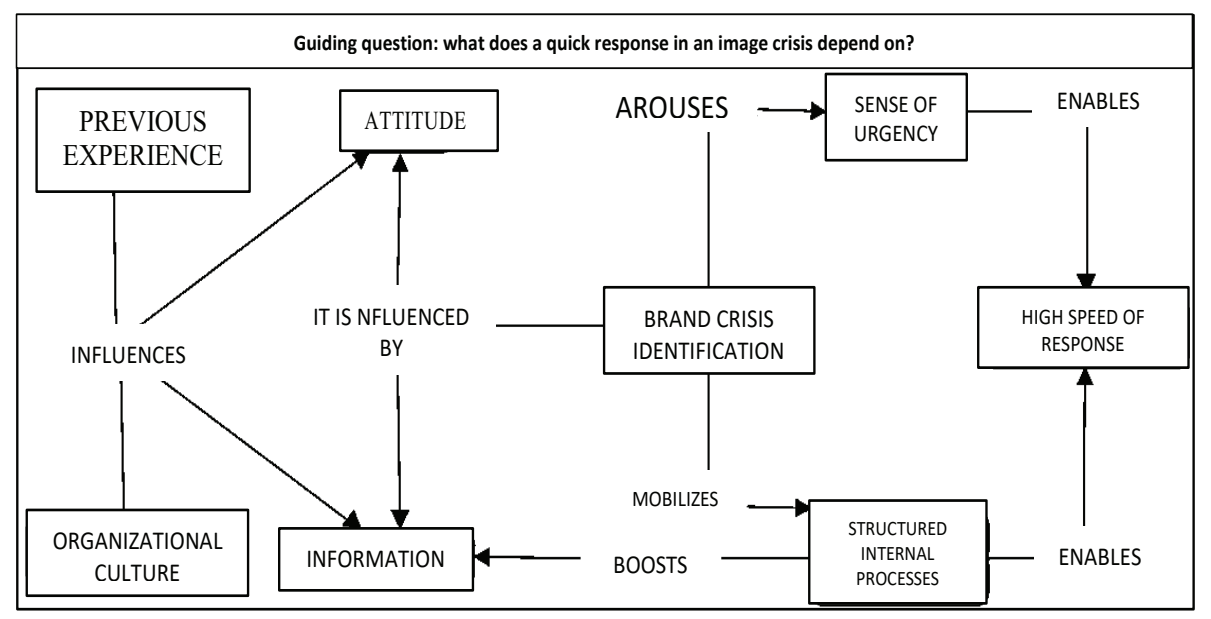

Figure 5. Conceptual map on the influences of the brand crisis, for a quick response in image crisis.

\section{I Academic, managerial and social implications}

To date, research on brand crisis management have investigated the background of a crisis (Coombs \& Jean, 2014; Dawar \& Lei, 2009; Siomkos et al., 2010). They also investigated the effects of crises on the brand and business, the communication and the monitoring of social networks (Hood, 2012; K. Kim et al., 2017; Koerber \& Zabara, 2016; Ngai \& Falkheimer, 2017; Pace et al., 2015; Park, 2016; Roh, 2017; Roshan et al., 2016; Rubel et al., 2011; Salvador et al., 2015, 2017) the \{IKEA $\}$ cuddle toy Lufsig was connoted as a symbol of the Chief Executive (CE. In addition they also investigated the use of information on crisis management (Barakat, Shatnawi, \& Ismail, 2016; Salvador \& Ikeda, 2015).

In order to contribute to the expansion of academic knowledge in the field of marketing management and brand crisis management, this study presented the cross-references of three different fields (information systems, brand crisis management and organizational development) to structure the knowledge of brand management crisis from the managers' perspective. It is of great importance the information enhancement allied to the action. Previous managerial experience and an organizational culture of information enhancement for decision-making can lead to increased sense of urgency and appreciation of market and internal data monitoring information, improving prevention and anticipating the identification of problems that could evolve into brand crises. The research also identified four profiles regarding the use of information in brand crisis management. This study highlights the importance of deepening the academic research on the factors that influence the crisis management, whether systemic or behavioral. 
From the managerial perspective, some crises could be avoided by monitoring internal and external information and identifying problems in the early stages. Others could have their effects minimized with a good use of the information and decision-making agreed upon by multifunctional committees, which increase the likelihood of leadership of the crisis communication process. The awareness of the brands' fragility, the increase in the availability of information for decisionmaking, the possibility of reducing the number of problems causing crisis and the possibility of rapid identification of a generative problem of a brand crisis may be sufficient to create the sense of urgency needed for the behavioral change. If not, the literature on change management points to the need to change the manager.

The reduction of brand crisis cases positively affects society as a whole (organizations and individuals), by reducing the financial losses of companies, reducing psychological harm to society and, finally, reducing possible physical damage to consumers directly involved.

\subsection{Limitations and suggestions for upcoming studies}

The research presents the expected limitations of the exploratory method use, which makes possible the increase of knowledge about a particular field, but it is not conclusive nor can be extended to the universe of knowledge. As a suggestion for future studies, we suggest researchers explore the factors that lead managers to value information and the mechanisms that lead them to act in the face of information. Such future researchers can evolve this exploratory study to conclusive studies, showing the managers' distribution of a particular economic sector or correlating the managers' profile with the success in crisis management; finally, they could study the difference in the state of readiness among companies that have faced or not brand crises. The complacent manager profile can be a result of corporate culture, of the status quo appreciation, of the resources limited vision, of conflicting goals and of the employees' demotivation (W. C. Kim \& Mauborgne, 2011; Kotter, 1997). The study of the influence of corporate culture in times of crisis is an important point of intersection for an interdisciplinary research among marketing, organizational development and strategy.

\section{References}

Aguiar, J. G. de, \& Correia, P. R. M. (2013). Como fazer bons mapas conceituais? Estabelecendo parâmetros de referências e propondo atividades de treinamento. Revista Brasileira de Pesquisa em Educação em Ciências, 13(2), 141-157.

Barakat, H. J., Shatnawi, H. A., \& Ismail, S. T. (2016). The role of marketing information systems in reducing the effects of the international financial crisis : A study applied on the banks working in the Kingdom of Saudi Arabia from Islamic Perspective. International Journal of Marketing Studies, 8(1), 181-190. doi:http://doi. org/10.5539/ijms.v8n1p181

Berenson, C. (1969). Marketing information systems. Journal of Marketing, 33(4), 16-23. doi:http://doi.org/10.2307/1248668

Biesdorf, S., Court, D., \& Willmott, P. (2013). Big data: What's your plan? McKinsey Quarterly. Recovered from http://www.mckinsey.com/ business-functions/digital-mckinsey/our-insights/ big-data-whats-your-plan

Bridges, W. (1986). Managing organizational transitions. Organization Dynamics, 15(1), 24-35. Recovered from http://ac.elscdn.com/ $0090261686900239 / 1$-s2.0 0090261686900239-main.pdf?_tid=4223f $2 \mathrm{ca}$ 28f9-1 1 e6-a309-00000aacb35d \&acdnat= 1464 896350_7eb8abeae246b04eae4df302e8871536

Bridges, W., \& Mitchell, S. (2000). Leading transition: A new model for change. Leader to Leader. Recovered from http://world.edu/ wp-content/uploads/2012/10/WilliamBridges TransitionandChangeModel_000.pdf 
Brown, B., Chui, M., \& Manyika, J. (2011, October). Are you ready for the era of "big data"? McKinsey Quarterly. Recovered from http://www. mckinsey.com/business-functions/strategy-andcorporate-finance/our-insights/are-you-ready-forthe-era-of-big-data

Chiusoli, C. L. (2005). Um estudo exploratório sobre tipologia e sistema de informação de marketing (Tese de doutorado). Faculdade de Economica, Administração e Contabilidade, Universidade de São Paulo - USP, São Paulo, SP, Brasil. Recovered from http://www.teses.usp.br/teses/ disponiveis/12/12139/tde-24012006-144741/ pt-br.php

Chow-White, P. A., \& Green, S. E. (2013). Data mining difference in the age of big data: Communication and the social shaping of genome technologies from 1998 to 2007. International Journal of Communication, 7, 556-583.

Cleeren, K., Van Heerde, H., \& Dekimpe, M. G. (2013). Rising from the ashes: How brands and categories can overcome product-harm crises. Journal of Marketing, 77(2), 58-77.

Coombs, W. T. (2007a). Attribution theory as a guide for post-crisis communication research. Public Relations Review, 33(2), 135-139. doi:http://doi.org/10.1016/j.pubrev.2006.11.016

Coombs, W. T. (2007b). Protecting organization reputations during a crisis: The development and application of situational crisis communication theory. Corporate Reputation Review, 10(3), 163-176. doi:http://doi.org/10.1057/palgrave. crr. 1550049

Coombs, W. T., \& Holladay, S. J. (2002). Helping crisis managers protect reputational assets: Initial tests of the situational crisis communication theory. Management Communication Quarterly, 16(2), 165-186. doi:http://doi. org/10.1177/089331802237233
Coombs, W. T., \& Jean, S. (2014). How publics react to crisis communication efforts. Journal of Communication Management, 18(1), 40-57.

Cox, D., \& Good, R. (1967). How to build a marketing information system. Harvard Business Review, 45(3), 145-154.

Dawar, N., \& Lei, J. (2009). Brand crises: The roles of brand familiarity and crisis relevance in determining the impact on brand evaluations. Journal of Business Research, 62(4), 509-516. doi:http://doi.org/10.1016/j.jbusres.2008.02.001

Dawar, N., \& Pillutla, M. M. (2000). Impact of product harm crises on brand equity: The moderating role of consumer expectations. Journal of Marketing Research, 37(2), 215-226.

Dijcks, J.-P. (2013, June). Oracle: Big data for the enterprise [An Oracle White Paper]. Oracle Corporation, Redwood Shores, CA, USA. Recovered from http://www.oracle. com/us/products/database/big-data-forenterprise-519135.pdf

Erdem, T., Swait, J., Broniarczyk, S., \& Kapferer, J.-N. (1999). Brand equity, consumer learning and choice. Marketing Letters, 10(3), 301318. Recovered from http://link.springer.com/ article/10.1023/A:1008135224357

Flick, U. (2004). Uma introdução à pesquisa qualitativa (2a ed.). Porto Alegre: Bookman.

Gensler, S., Völckner, F., Liu-Thompkins, Y., \& Wiertz, C. (2013). Managing brands in the social media environment. Journal of Interactive Marketing, 27(4), 242-256. doi:http://doi. org/10.1016/j.intmar.2013.09.004

Gobble, M. M. (2013). Big data: The next big thing in innovation. Research-Technology Management, 56(1), 64-67. doi:http://doi. org/10.5437/08956308X5601005

Godoi, C. K., \& Mattos, P. L. C. L. de. (2006). Entrevista qualitativa: Instrumento de pesquisa e 
evento dialógico. In C. K. Godoi, R. Bandeirade-Melo, \& A. B. da Silva, Pesquisa Qualitativa em estudos organizacionais: Paradigmas, estratégias e métodos (pp. 301-323). São Paulo: Saraiva.

Greyser, S. A. (2009). Corporate brand reputation and brand crisis management. Management Decision, 47(4), 590-602. doi:http://doi. org/10.1108/00251740910959431

Hakala, U., Svensson, J., \& Vincze, Z. (2012). Consumer-based brand equity and top-of-mind awareness: A crosscountry analysis. Journal of Product \& Brand Management, 21(6), 439-451. doi:http://doi. org/10.1108/10610421211264928

Hood, M. (2012). The Tiger Woods scandal: A cautionary tale for event studies. Managerial Finance, 38(5), 543-558. doi:http://doi. org/10.1108/03074351211217850

Kalaignanam, K., Kushwaha, T., \& Eilert, M. (2013). The impact of product recalls on future product reliability and future accidents: Evidence from the automobile industry. Journal of Marketing, 77(2), 41-57.

Kaplan, A. M., \& Haenlein, M. (2010). Users of the world, unite! The challenges and opportunities of social media. Business Horizons, 53(1), 59-68. doi:http://doi.org/10.1016/j.bushor.2009.09.003

Keagan, R., \& Lahey, L. L. (2011). The real reason people won't change. In HBR's 10 must reads on change management (pp. 119-136). Boston: Havard Business Review Press.

Kim, K., Kim, J., \& Reid, L. N. (2017, June). Experiencing motivational conflict on social media in a crisis situation: The case of the Chickfil-A same-sex marriage controversy. Computers in Human Behavior, 71, 32-41. doi:http://doi. org/10.1016/j.chb.2017.01.035

Kim, W. C., \& Mauborgne, R. (2011). Tipping point leadership. In HBR's 10 must reads on change management (pp. 49-62). Boston: Havard Business Review Press.

Kliatchko, J. (2008). Revisiting the IMC construct: A revised definition and four pillars. International Journal of Advertising, 27(1), 133160.

Koerber, D., \& Zabara, N. (2016). Preventing damage: The psychology of crisis communication buffers in organized sports. Public Relations Review, 43(1), 193-200. doi:http://doi.org/10.1016/j. pubrev.2016.12.002

Kotter, J. P. (1997). Liderando mudanças. São Paulo: Elsevier.

Kotter, J. P. (2012, November). Accelerate! How the most innovative companies capitalize on today's rapid-fire strategic challenges and still make their numbers. Harvard Business Review, 9O(11), 44-59. doi:http://doi.org/10.1057/ palgrave.crr. 1540128

Laroche, M., Habibi, M. R., Richard, M.-O., \& Sankaranarayanan, R. (2012). The effects of social media based brand communities on brand community markers, value creation practices, brand trust and brand loyalty. Computers in Human Behavior, 28(5), 1755-1767. doi:http:// doi.org/10.1016/j.chb.2012.04.016

Lovett, M. J., Peres, R., \& Shachar, R. (2013). On Brands and Word of Mouth. Journal of Marketing Research, L(Auguste), 427-444.

Manyika, J., Chui, M., Brown, B., Bughin, J., Dobbs, R., Roxburgh, C., \& Byers, A. H. (2011). Big data: The next frontier for innovation, competition, and productivity. Recovered from http://www.mckinsey.com/business-functions/ digital-mckinsey/our-insights/big-data-the-nextfrontier-for-innovation

Marshall, C., \& Rossman, G. (1995). Designing qualitative research (2nd ed.). Thousand Oaks: SAGE Publications Inc. Recovered from http:// 
books.google.com/books?hl=en \&lr=\&id=Rbq XGjKHALoC\&oi $=$ fnd \& pg =PR $1 \& d q=$ Design ing+Qualitative+Research\&ots=BMdEvq_81 \&sig=1cv3ycBDj-CjGxsFCUfheGtCrjk

Mayring, P. (2014). Qualitative content analysis: Theoretical foundation, basic procedures and software solution. Klagenfurt: Beltz. Recovered from http://www.ssoar.info/ssoar/bitstream/ handle/document/39517/ssoar-2014-mayringQualitative_content_analysis_theoretical_ foundation.pdf?.sequence $=1$

Ngai, S. B. C., \& Falkheimer, J. (2017). How IKEA turned a crisis into an opportunity. Public Relations Review, 43(1), 246-248. doi:http://doi.org/http:// dx.doi.org/10.1016/j.pubrev.2016.12.003

Onwuegbuzie, A. J., \& Leech, N. L. (2005). On becoming a pragmatic researcher: The importance of combining quantitative and qualitative research methodologies. International Journal of Social Research Methodology, 8(5), 375-387. doi:http:// doi.org/10.1080/13645570500402447

Pace, S., Balboni, B., \& Gistri, G. (2015, December). The effects of social media on brand attitude and WOM during a brand crisis : Evidences from the Barilla case. Journal of Marketing Communications, 23(2), 135-148. doi:http://doi.org/10.1080/13527266.2014.96 6478

Park, H. (2016). Exploring effective crisis response strategies. Public Relations Review, 43(1), 190-192. doi:http://doi.org/10.1016/j. pubrev.2016.12.001

Roh, S. (2017). Examining the paracrisis online: The effects of message source, response strategies and social vigilantism on public responses. Public Relations Review, 43(3), 587-596. doi:http://doi. org/10.1016/j.pubrev.2017.03.004

Rosa, M. (2001). Como lidar com crises de imagem: A sindorme de Aquiles. São Paulo: Ed. Gente.
Roshan, M., Warren, M., \& Carr, R. (2016, October). Understanding the use of social media by organisations for crisis communication. Computers in Human Behavior, 63, 350-361. doi:http://doi.org/10.1016/j.chb.2016.05.016

Rouach, D., \& Santi, P. (2001). Competitive intelligence adds value: Five intelligence attitudes. European Management Journal, 19(5), 552-559. doi:http://doi.org/10.1016/S02632373(01)00069-X

Rubel, O., Naik, P. A., \& Srinivasan, S. (2011). Optimal advertising when envisioning a productharm crisis. Marketing Science, 30(6), 1048-1065. doi:http://doi.org/10.1287/mksc.1110.0679

Salvador, A. B., \& Ikeda, A. A. (2015). Big data na gestão de crise de marca: Um ensaio exploratório. RIMAR, 5(1), 3-14.

Salvador, A. B., Ikeda, A. A., \& Crescitelli, E. (2017). Gestão de crise e seu impacto na imagem de marca. Gestão \& Produção, 24(1), 15-24.

Salvador, A. B., Strehlau, V. I., \& Ikeda, A. A. (2015). Local crisis of global brand and monitoring of use of social media. Remark, 14(4), 438-450. http://doi.org/10.5585/remark. v14i4.2964

Schlesinger, L. A. (2008, July-August). Choosing strategies for change. Harvard Business Review, 86(7-8), 130-139.

Selltiz, C. (1974). Método de pesquisa nas relaçôes sociais. São Paulo: Editora Pedagógica e Universitária Ltda.

Semprini, A. (2010). A marca pós-moderna (2a ed.). São Paulo: Estação das Letras e Cores.

Sherry, J. F., Jr. (2006). O significado da marca. In A. M. Tybout \& T. Calkins (Eds.), Branding (pp. 40-69). São Paulo: Atlas.

Silva, B. R., Neto (2010). Comunicação corporativa e reputaçâo: Construçâo e defesa da imagem favorável. São Paulo: Saraiva. 
Siomkos, G., Triantafillidou, A., Vassilikopoulou, A., \& Tsiamis, I. (2010). Opportunities and threats for competitors in product-harm crises. Marketing Intelligence \& Planning, 28(6), 770-791. doi:http:// doi.org/10.1108/02634501011078156

Sirkin, H., Keenan, P., \& Jackson, A. (2011). The hard side of change management. In HBR's 10 must reads on change management (pp. 97-109). Boston: Havard Business Review Press.

Yin, R. K. (1998). How to do better case studies. In L. Bickman \& D. J. Rog (Eds.), The SAGE handbook of applied social research methods (2nd ed., Chap. 8, pp. 254-282). Thousand Oaks: SAGE Publications Inc.

\section{Notes}

1 A preliminary version of this article was presented as «Perfis de Gestores de Crise. Um estudo exploratório»at Semead in 2015. With the insights gained at the congress, the study was restructured and presented at CLAV 2016 as «Perfis de Gestores de Crise. Um estudo exploratório»

\section{Supporting agencies:}

Coordination for the Improvement of Higher Education Personnel (CAPES)

\section{About the authors:}

1. Alexandre Borba Salvador, Master and Doctorate Student in Business Management, FEA-USP, São Paulo, Brazil. E-mail: alexandre.salvador@usp.br

\section{ORCID}

(iD) 0000-0002-5318-0805

2. Ana Akemi Ikeda, Doctor in Business Management and Full Professor, FEA-USP, São Paulo, Brazil. E-mail: anaikeda@usp.br

\section{ORCID}

(D) 0000-0002-2364-6416

\section{Contribution of each author}

\begin{tabular}{lcc}
\hline Contribution & Alexandre Borba Salvador & Ana Akemi Ikeda \\
\hline 1. Definition of research problem & $\sqrt{ }$ \\
2. Development of hypotheses or research questions (empirical studies) & $\sqrt{ }$ \\
3. Development of theoretical propositions (theoretical work) & - \\
4. Theoretical foundation/ Literature review & $\sqrt{ }$ \\
5. Definition of methodological procedures & $\sqrt{ }$ \\
6. Data collection & $\sqrt{ }$ \\
7. Statistical analysis & - \\
8. Analysis and interpretation of data & $\sqrt{ }$ \\
9. Critical revision of the manuscript & $\sqrt{ }$ \\
10. Manuscript writing & $\sqrt{ }$ \\
11. General orientation & \\
\hline
\end{tabular}

